and a considerable number have been revised and re-written, particularly those on digitalis, pituitary, atoxyl, and salvarsan.

The volume runs to about four hundred and fifty pages and contains a good index. The account given of the various drugs is clear and accurate and is presented in a suitable manner to the student. The subject-matter is illustrated with diagrams and tracings which materially assist in the proper understanding of the meaning the author wishes to convey. The book is a valuable one and has evidently a big sale in America. Except as a book of reference, it is not likely to displace the text-books students make use of in this country, although the volume is not inferior in any way to the best of the numerous volumes published on the subject. The publishers deserve a special word of praise for the most excellent manner of the productionthe paper, print, and illustrations being all that could be desired.

\section{An Index of Differential Diagnosis of Main} Symptoms. - By various writers. Edited by Herbert French, m.A., M.D. (Oxon.), F.r.c.P. (Lond.), Physician, Pathologist, and Lecturer, Guy's Hospital, etc. Second Edition. 37 Coloured Plates and over 300 Illustrations in the text. Bristol : John Wright and Sons, Ltd., 1917.

THIs book is too well-known, and the first edition (of which several reprints were necessary) was so highly esteemed by the medical profession that no words of commendation on our part would be likely to be required by the medical profession in India.

However it is, perhaps, necessary to chronicle the advent of a new edition in which every article has been revised and in which many new ones have been added. In addition, the elaborate index, which formed a marked feature of the former edition, has been extended and the relative importance of the entries have been indicated by the use of those different degrees of type. The illustrations are doubled and the coloured plates increased from sixteen to thirty-seven; a special feature, which will appeal to all of us as we grow older, is that the type used in the text has been increased in size-this has naturally led to the use of an enlarged page.

The value of this book to all teaching and practising physicians and surgeons and to all senior students could not well be overestimated. Speaking from personal experience as a teacher, the volume has been of the very greatest help, and we have very seldom turned to its pages in vain when desirous of refreshing the memory or examining new work on a subject.

This is a volume that should constantly be in the hands of every practitioner; the very favourable way in which the first edition was received shows the appreciation of the medical profession to the excellent material collected and edited by the author. We need bardly say that the publishers have risen to the occasion and have spared neither trouble nor expense in placing a volume at the disposal of the profession of which both they and the author have every reason to be proud.

\section{âtledical Sorocitto.}

\section{MEDICAL MEETING, RANGOON}

\section{Morphia Injector's SEPTICAmia.}

Aт a meeting of the Burma Assistant Surgeons, Association the following paper was read by Dr. C. S. Krishnasawmy on the peculiar disease first described in Rangoon and known as Whitmore's disease, or Morphia Injector's Septicæmia.

Soon after my taking over sub-charges of the Pathological and Post-Mortem Department of the Rangoon General Hospital towards the end of April 1910, I found that there was an enormous amount of pathological material available in Rangoon that required accurate working up and noting down for further research; so I began right earnestly to do so under the inspiring personality of Captain A. Whitmore, who has been my chief for the last five years and to whom my sincere thanks are due for the cheerful encouragement and ungrudging guidance which have largely contributed to my working out of this disease. Both of us first published our results in the Indian Medical Gazette of July 1912 and, later on, one of us (A. W.) again in the journal of Bygiene of April 1913, reviewing altogether about forty cases ; Captain Whitmore opened a discussion at the Bacteriological Section of the eightieth annual meeting of the British Medical Association in the third week of July 1912, reviewing the same number of cases. Major Knapp, I.M.S., published the reports of a few cases in the Indian Medical Gazette of August 1915. But, since then, as no further or continuous report of the disease has been published, I propose to review the disease as I have personally seen it for the last six years, covering over two hundred cases. These cases include those seen in the mortuary and wards of the Rangoon General Hospital and those from the Rangoon Jail, whose reports have been published and whose pathological examinations were undertaken by us, and the case I recently had in the Lunatic Asylum sent in by a medical practitioner from outside.

\section{Early History of the Disease.}

During May and June 1910, when we were having a few cases of human glanders admitted into the Rangoon General Hospital, which we reported to the Health and Veterinary Officers of the Rangoon Municipality, I noticed in the Post-Mortems done during that period that there were cases of Broncho-Pneumonia having almost the same pathological lesions in the lungs as glanders, but less acute, and in persons who had apparently nothing to do with horses and from whose lesions typical glanders bacilli could not be isolated by culture, thus throwing some doubt on the real nature of the 